\title{
Productivity and Economics of Rice-Wheat Cropping System under Irrigation, Nutrient and Tillage Practices in a Silty Clay Loam Soil
}

\author{
Tanumay Mandal", Subhash Chandra and Gurvinder Singh \\ Department of Agronomy, GBPUA\&T, Pantnagar, Uttarakhand-263145, India \\ *Corresponding author
}

\begin{tabular}{|c|}
\hline Keywords \\
\hline $\begin{array}{l}\text { Conventional, } \\
\text { Shallow, Zero tillage, } \\
\text { NPK, Irrigation, } \\
\text { Yield, Economics }\end{array}$ \\
\hline Article Info \\
\hline $\begin{array}{l}\text { Accepted: } \\
07 \text { February } 2018 \\
\text { Available Online: } \\
10 \text { March } 2018\end{array}$ \\
\hline
\end{tabular}

\section{A B S T R A C T}

Field experiments were conducted in two consecutive kharif and rabi seasons of 2013-14 and 2014-15 at $\mathrm{A}_{1}$ block of N. E. Borlaug Crop Research Centre of Govind Ballabh Pant University of Agriculture \& Technology, Pantnagar (Uttarakhand) to study the effect of irrigation, fertilizer and tillage practices on productivity and economics of rice-wheat cropping system in a silty clay loam soil. The experiment was laid out in split-plot design with three replications. The experiment was comprised of two levels of irrigation (3 days after disappearance of surface water (DADSW) and 6 DADSW for rice and CRI+IW: CPE 0.75 and CRI+IW: CPE 0.5 for wheat), two levels of NPK (120:60:40 and 90:45:30 for rice and 150:60:40 and 113:45:30 for wheat) and three tillage practices (puddled transplanting-conventional tillage; unpuddled transplanting - shallow tillage and zero tillage transplanting-zero tillage, respectively for rice-wheat). The irrigation levels did not affect significantly the grain and straw yields as well as on economics of both the crops. During both the years, application of NPK @ 120:60:40 and 150:60:40 recorded significantly higher grain and straw yields than 90:45:30 and 113:45:30, respectively of rice and wheat. The gross, net return and benefit: cost ratio was also higher at higher dose of NPK than lower dose during both the years for both the crops. For rice, puddled transplanting recorded the highest grain and straw yield closely followed by unpuddled transplanting, whereas the lowest was with zero tillage transplanted rice during both the years. For wheat, conventional tillage recorded the maximum grain yield closely followed by shallow tillage in both the years. The net return and B: C ratio were the highest for unpuddled transplanted rice, while for wheat though the net return was the highest with shallow tillage but benefit: cost ratio with zero tillage.

\section{Introduction}

The rice-wheat cropping system is the backbone of India's food security. This enabled rice-wheat to emerge as the major cropping system in the Indo-Gangetic Plains (IGP) leading to the Green Revolution. In Asia, the rice-wheat system is practiced around 24.5 Mha, including China with about
10 Mha, and South Asia with about 14.5 Mha. The area of rice-wheat system in India, Pakistan, Bangladesh and Nepal is 11.0, 2.2, 0.8 , and 0.5 Mha, respectively. Rice-wheat system represents 32 and 42 per cent of the global rice and wheat area, respectively in these countries (Ladha et al., 2000). Rice is generally transplanted in puddled soils with continued submergence. A huge amount of 
water is used to maintain flooding in rice field. Rice grown employing traditional practices require approximately $1500 \mathrm{~mm}$ of water during a season and around $50 \mathrm{~mm}$ of water to grow seedlings. The actual amount of water applied by farmers, however, is much higher than the requirement. As the availability of water is decreasing day by day; therefore its judicious use is of utmost significance to improve the water and crop productivity. In this regard optimization of irrigation schedule can play an important role.

The basic objective of irrigation is to maintain the soil moisture at a level not detrimental to the crop. Lourduraj and Bayan (1999) reported that irrigation in rice could be withheld for two to three days after disappearance of ponded water without any reduction in grain yield. Pradhan et al., (2013) observed that grain yield of wheat was increased with the increase in levels of irrigation. It was significantly higher in 0.8 and $1.0 \mathrm{IW} / \mathrm{CPE}$ irrigation levels than 0.4 and $0.6 \mathrm{IW} / \mathrm{CPE}$ irrigation levels.

Rice and wheat both crops are exhaustive in nature thus remove large quantity of nutrients from soil. At the productivity level of 9 tones grain per hectare, these crops remove approximately $204 \mathrm{~kg} \mathrm{~N}, 30 \mathrm{~kg} \mathrm{P}$ and $247 \mathrm{~kg}$ $\mathrm{K}$ per hectare (Mundra et al., 2003). Use high yielding varieties (HYVs) and imbalanced use of fertilizer combined with conventional method of planting have resulted in declining crop yields and lowering soil fertility (Bisht $e t$ al., 2006). Now, the system has witnessed serious problems viz., plateauing yield, declining factor productivity and deteriorating soil health. Gupta et al., (2011) reported that increasing fertilizer dose from 75 to $100 \%$ of recommended dose significantly increased grain and straw yields of rice and wheat.

The conventional method of land preparation in the rice-wheat system disturbs the soil environment. Puddling in rice achieved by repeated intensive tillage under ponded-water conditions, break down soil aggregates, reduce macro-porosity, reduce soil strength in the puddled layer, disperse fine clay particles and form a plow-pan in subsoil Wetland rice culture thus destroys soil structure and creates a poor physical condition for the succeeding wheat crop.

Evidence shows that this system is now showing signs of fatigue and yields of rice and wheat in this region have reached a plateau or are declining, the soils have deteriorated, the groundwater table is receding at an alarming rate, total factor productivity or input-use efficiency is decreasing, cultivation costs are increasing, profit margins are reducing, and the simple agronomic practices that revolutionized rice-wheat cultivation in the IGP are fast losing relevance (Hobbs and Morris, 1996).

Various limitations cited above with continuous rice-wheat cropping system under conventional ways of cultivation have raised several questions about its sustainability both in terms of crop and soil productivity and environmental health. The higher cost of cultivation is yet another bottle-neck to continue with this rotation. In silty clay loam (heavy soil) these problems are still more severe. Inspite of all odds, the rice-wheat system cannot be completely eradicated from the agricultural production system, as both are the major food crops. However, crop management practices can be altered to mitigate the adverse effects of ongoing cultivation practices. One of the aspects is crop residue management, by way of conservation tillage. These includes zero tillage, FIRBs, reduced tillage etc. However, in heavy soils, the advantage of zero tillage could not be exploited to its maximum due to certain practical reasons like poor crop establishment, poor root growth and so on. 
Thus to find out suitable tillage practices with irrigation and nutrient level for rice-wheat cropping system, this study was conducted.

\section{Materials and Methods}

Field experiments were conducted in the two consecutive kharif and rabi seasons of 201314 and 2014-15 at $A_{1}$ block of N. E. Borlaug Crop Research Centre of Govind Ballabh Pant University of Agriculture and Technology, Pantnagar (Uttarakhand) to study the effect of irrigation, fertilizer and tillage on rice-wheat cropping system. Geographically, Pantnagar is situated at $29^{\circ} \mathrm{N}$ latitude, $79.3^{\circ} \mathrm{E}$ longitude, at an altitude of $243.84 \mathrm{~m}$ above the mean sea level in the tarai belt of Shivalik range of Himalayan foot hills. The experiment was laid out in split-plot design with three replications, consisting two levels of irrigation [3 days after disappearance of surface water (DADSW) and 6 DADSW for rice and CRI+IW:CPE 0.75 and CRI+IW:CPE 0.5 for wheat), two levels of NPK (120:60:40 and 90:45:30 for rice and 150:60:40 and 113:45:30 for wheat) and three tillage practices (conventional, reduced and zero)]. In rice, conventional was puddled transplanting (PT), reduced tillage was unpuddled transplanting (UPT) and zero tillage transplanting (ZTT). In wheat, conventional was good land preparation (CT), reduced tillage was shallow tillage (ST) disturbing only top 6-8 $\mathrm{cm}$ soil layer and zero tillage (ZT). In reduced and zero tillage, the stubbles of preceding crop upto height of 30 $\mathrm{cm}$ were retained, while in conventional the crop was cut close to the ground surface. The study was made in fixed plots. The soil of the experimental site was silty clay loam in texture having medium organic carbon $(0.74 \%)$, available $\mathrm{P}_{2} \mathrm{O}_{5}(53.1 \mathrm{~kg} / \mathrm{ha})$ but low in available nitrogen $(230.3 \mathrm{~kg} / \mathrm{ha})$ and very low available $\mathrm{K}_{2} \mathrm{O}(124.5 \mathrm{~kg} / \mathrm{ha})$ with $\mathrm{pH}$ of 7.9. Rice variety 'Narendra 359' and wheat variety 'UP 2748' were used for the experiment. Both the crops were raised using standard practices, except the treatments. The rainfall received during rice season was 1013.4 and $569.8 \mathrm{~mm}$ in 2013 and 2014, respectively whereas wheat received 314.8 and $187.3 \mathrm{~mm}$ of rainfall in 2013-14 and 2014-15, respectively. Due to good rainfall, irrigations could not be applied to wheat after CRI, during both the years. Economics was worked out by using prevailing market price of inputs and outputs of both the crops.

\section{Results and Discussion}

\section{Effect on yield}

\section{Rice}

There was no significant effect of irrigation level on grain yield of rice but irrigation at 6 DADSW recorded numerically lower grain and straw yields of rice as compared to irrigation at 3 DADSW during both the years (Table 1). The small advantage in yield under relatively wet moisture regime was the outcome of better growth, development and partitioning of carbohydrates into different plant parts. Lawlor and Cornic (2002) also reported that photosynthetic inhibition is one of the primary detrimental effects of water stress.

Crop fertilized with NPK @ 120:60:40 recorded significantly higher grain and straw yield than 90:45:30 during both the years (Table 1). The increase in grain yield was 13.7 \& 6.3 and 9.2 \& 11.8 in 2013-14 and 2014-15 in rice and wheat, respectively. Enhanced grain yield with the increase in NPK application suggest that higher rates of nitrogen fertilizer are required to maintain yield potential. The increase in grain yield at higher $\mathrm{N}$ rate is mainly due to increased radiation interception driven by a rise in growth rate, which ultimately increased grain yield (Fan et al., 2005; Kibe et al., 2006). During 2013, the grain yield was not affected 
significantly by tillage practices but PT recorded 3.8 and 4.9 per cent higher grain yield than UPT and ZTT, respectively (Table 1). In 2014, PT recorded significantly 5.2 and 18.6 per cent higher grain yield than UPT and ZTT, respectively. UPT also recorded significantly 12.6 per cent more grain yield than ZTT. During 2013, PT recorded significantly 15.1 and 16.7 per cent higher straw yield than UPT and ZTT, respectively. Like 2013, in 2014 also PT recorded significantly 6.6 and 14.1 per cent higher straw yield than UPT and ZTT, respectively. Further, UPT produced significantly 7.0 per cent more straw yield than ZTT. The mean grain and straw yield of rice was also highest in PT (5211 and $6347 \mathrm{~kg} / \mathrm{ha}$ ) followed by UPT (4982 and $5732 \mathrm{~kg} / \mathrm{ha}$ ) and ZTT (4674 and $5500 \mathrm{~kg} / \mathrm{ha}$ ).

The conventional tillage might have favoured the roots to proliferate to extract more nutrients and moisture that has led to higher growth and yield of rice. Higher tillage depth favourably influenced the soil-water-plant ecosystem, thereby improved crop yields and quality (Ardell et al., 2000). In a silty clay loam texture soil, due to more clay content, it may be expected. During second year, the decrease in grain yield under ZTT as compared to PT was more compared to first year. It was due to compaction of top soil layer and infestation of perennial weeds under undisturbed conditions.

\section{Wheat}

The grain and straw yield of wheat during both the years was not affected significantly by irrigation levels (Table 1). During both the years, good amount of rainfall (314.8 and $187.3 \mathrm{~mm}$ in 2013-14 and 2014-15, respectively) was received, thus irrigation could not be applied. Application of NPK @ 150:60:40 recorded significantly higher grain and straw yield than 113:45:30 during both the years (Table 1). The increase in grain and straw yield may be due to the availability of NPK at various critical crop growth stages in optimal amount which might have accelerated photosynthetic activities, resulting increase in yield attributes of wheat thus resulting in the increased grain and straw yield. This is in conformity with the findings of Kumar and Yadav (2005).

During both the years, the grain yield of CT and ST did not differ significantly. In 201314, CT and ST recorded (6.0 and 6.3\%, respectively) higher grain yield than $\mathrm{ZT}$, while in 2014-15, the magnitude of increase was 8.6 and 7.0 per cent (Table 1). During both the years, CT recorded significantly higher straw yield than ST and ZT. The increase was 19.3 and 23.3 per cent in 2013-14 and 6.2 and 14.3 percent in 2014-15. Further, ST recorded significantly 7.7 percent more straw yield than ZT in 2014-15. The mean grain and straw yield of wheat of two years was also highest in CT (3880 and $5177 \mathrm{~kg} / \mathrm{ha}$ ) followed by ST (3859 and 4602kg/ha) and ZT (3618 and 4362 $\mathrm{kg} / \mathrm{ha})$. Gupta et al., (2011) and Surin et al., (2013) also reported that conventional tillage gave the highest grain yield than zero tillage system. Chauhan and Ward (1992) supported to the findings that conventionally sown wheat gave 10-13 and 28-35 per cent higher grain yield than raised bed and zero tillage sown wheat, respectively in silty-clay loam soil.

In the heavy soil like silty clay loam soil, the zero tillage did not favour the roots to proliferate down into the deeper layers of the soil profile to extract nutrients and moisture that has led to lower growth and yield of wheat. The poor performance of wheat under ZT may further be supported by the fact that high infestation of perennial weeds and high bulk density in zero tillage causes poor germination, lower number of ear bearing shoots and ultimately lower grain yield (Singh et al., 1998 and Dash and Verma, 2003). 
Table.1 Grain and straw yield of transplanted rice, wheat and rice-wheat system as affected by irrigation, NPK levels and crop establishment methods

\begin{tabular}{|c|c|c|c|c|c|c|c|c|c|c|c|c|}
\hline \multirow{2}{*}{ Treatment } & \multicolumn{6}{|c|}{ Grain yield (kg/ha) } & \multicolumn{6}{|c|}{ Straw yield (kg/ha) } \\
\hline & 2013 & 2014 & Mean & 2013-14 & 2014-15 & Mean & 2013 & 2014 & Mean & 2013-14 & 2014-15 & Mean \\
\hline $\begin{array}{c}6 \text { DADSW/ } \\
\text { IW:CPE } 0.5\end{array}$ & 4870 & 4898 & 4884 & 3926 & 3552 & 3739 & 5814 & 5788 & 5801 & 4624 & 4726 & 4675 \\
\hline SEm \pm & 77 & 70 & - & 38 & 52 & - & 97 & 106 & - & 70 & 53 & - \\
\hline $\mathrm{CD}(\mathrm{P}=0.05)$ & NS & NS & - & NS & NS & - & NS & NS & - & NS & NS & - \\
\hline \multicolumn{13}{|l|}{ NPK level } \\
\hline $\begin{array}{l}90: 45: 30 / \\
113: 45: 30\end{array}$ & 4634 & 4807 & 4721 & 3775 & 3420 & 3598 & 5547 & 5641 & 5594 & 4506 & 4484 & 4495 \\
\hline SEm \pm & 77 & 70 & - & 38 & 52 & - & 97 & 106 & - & 70 & 53 & - \\
\hline $\mathrm{CD}(\mathrm{P}=0.05)$ & 267 & 241 & - & 132 & 181 & - & 335 & 366 & - & 242 & 183 & - \\
\hline \multicolumn{13}{|c|}{ Crop establishment method } \\
\hline $\mathrm{PT} / \mathrm{CT}$ & 5093 & 5328 & 5211 & 4021 & 3739 & 3880 & 6409 & 6285 & 6347 & 5269 & 5085 & 5177 \\
\hline UPT/ST & 4906 & 5058 & 4982 & 4032 & 3685 & 3859 & 5570 & 5894 & 5732 & 4415 & 4789 & 4602 \\
\hline ZTT/ZT & 4856 & 4492 & 4674 & 3792 & 3443 & 3618 & 5492 & 5507 & 5500 & 4275 & 4448 & 4362 \\
\hline SEm \pm & 111 & 57 & - & 61 & 64 & - & 124 & 74 & - & 91 & 88 & - \\
\hline $\mathrm{CD}(\mathrm{P}=\mathbf{0 . 0 5})$ & NS & 172 & - & 181 & 191 & - & 371 & 222 & - & 274 & 264 & - \\
\hline
\end{tabular}


Table.2 Economics of rice as influenced by irrigation, NPK levels and Crop establishment methods

\begin{tabular}{|c|c|c|c|c|c|c|c|c|}
\hline \multirow[t]{2}{*}{ Treatment } & \multicolumn{2}{|c|}{$\begin{array}{l}\text { Cost of cultivation } \\
\left(\text { Rs. ha } \text { ha }^{-1}\right)\end{array}$} & \multicolumn{2}{|c|}{$\begin{array}{c}\text { Gross return } \\
\text { (Rs. ha-1) }\end{array}$} & \multicolumn{2}{|c|}{$\begin{array}{c}\text { Net return } \\
\text { (Rs. ha-1) }\end{array}$} & \multicolumn{2}{|c|}{$\begin{array}{l}\text { B:C ratio } \\
\text { (Rs. ha-1) }\end{array}$} \\
\hline & 2013 & 2014 & 2013 & 2014 & 2013 & 2014 & 2013 & 2014 \\
\hline \multicolumn{9}{|l|}{ Irrigation level } \\
\hline 6 DADSW & 33988 & 39665 & 64958 & 68066 & 30970 & 28401 & 0.92 & 0.72 \\
\hline 3 DADSW & 35548 & 40865 & 67111 & 69771 & 31563 & 28906 & 0.89 & 0.71 \\
\hline SEm \pm & - & - & 1026 & 963 & 1026 & 963 & 0.03 & 0.02 \\
\hline $\mathrm{CD}(\mathrm{P}=0.05)$ & - & - & NS & NS & NS & NS & NS & NS \\
\hline \multicolumn{9}{|l|}{ NPK level } \\
\hline $90: 45: 30$ & 34087 & 39584 & 61815 & 66785 & 27728 & 27201 & 0.82 & 0.69 \\
\hline $120: 60: 40$ & 35449 & 40946 & 70255 & 71052 & 34805 & 30106 & 0.92 & 0.73 \\
\hline SEm+ & - & - & 1026 & 963 & 1026 & 963 & 0.03 & 0.02 \\
\hline $\mathrm{CD}(\mathrm{P}=0.05)$ & - & - & 3541 & 3323 & 3541 & NS & 0.10 & NS \\
\hline \multicolumn{9}{|c|}{ Crop establishment method } \\
\hline PT & 37815 & 43305 & 68006 & 74030 & 30191 & 30725 & 0.80 & 0.71 \\
\hline UPT & 33215 & 38705 & 65387 & 70263 & 32172 & 31558 & 0.97 & 0.82 \\
\hline ZTT & 33275 & 38785 & 64712 & 62464 & 31437 & 23679 & 0.94 & 0.61 \\
\hline SEm & - & - & 1469 & 787 & 1469 & 787 & 0.04 & 0.02 \\
\hline $\mathrm{CD}(\mathrm{P}=0.05)$ & - & - & NS & 2359 & NS & 2359 & 0.13 & 0.06 \\
\hline
\end{tabular}

Table.3 Economics of wheat as influenced by irrigation, NPK levels and Crop establishment methods

\begin{tabular}{|c|c|c|c|c|c|c|c|c|}
\hline \multirow[t]{2}{*}{ Treatment } & \multicolumn{2}{|c|}{$\begin{array}{c}\text { Cost of cultivation } \\
\text { (Rs. ha-1) }\end{array}$} & \multicolumn{2}{|c|}{$\begin{array}{l}\text { Gross return } \\
\text { (Rs. ha-1) }\end{array}$} & \multicolumn{2}{|c|}{$\begin{array}{l}\text { Net return } \\
\text { (Rs. ha-1) }\end{array}$} & \multicolumn{2}{|c|}{$\begin{array}{l}\text { B:C ratio } \\
\text { (Rs. ha-1) }\end{array}$} \\
\hline & $2013-14$ & $2014-15$ & 2013-14 & $2014-15$ & 2013-14 & $\begin{array}{c}2014- \\
15\end{array}$ & $\begin{array}{c}2013- \\
14\end{array}$ & $\begin{array}{c}2014- \\
15\end{array}$ \\
\hline \multicolumn{9}{|l|}{ Irrigation level } \\
\hline IW:CPE 0.50 & 23859 & 24172 & 57155 & 53957 & 33296 & 29785 & 1.40 & 1.24 \\
\hline IW:CPE 0.75 & 23859 & 24172 & 57814 & 56037 & 33955 & 31865 & 1.43 & 1.32 \\
\hline SEm \pm & - & - & 571 & 780 & 571 & 780 & 0.02 & 0.03 \\
\hline $\mathrm{CD}(\overline{\mathrm{P}}=\mathbf{0 . 0 5})$ & - & - & NS & NS & NS & NS & NS & NS \\
\hline \multicolumn{9}{|l|}{ NPK level } \\
\hline $113: 45: 30$ & 23132 & 23445 & 54989 & 51917 & 31857 & 28471 & 1.39 & 1.22 \\
\hline $150: 60: 40$ & 24585 & 24898 & 59980 & 58077 & 35395 & 33179 & 1.45 & 1.34 \\
\hline SEm \pm & - & - & 571 & 780 & 571 & 780 & 0.02 & 0.03 \\
\hline $\mathrm{CD}(\mathrm{P}=0.05)$ & - & - & 1971 & 2693 & 1971 & 2693 & NS & 0.11 \\
\hline \multicolumn{9}{|c|}{ Crop establishment method } \\
\hline CT & 26149 & 26459 & 59450 & 57567 & 33302 & 31108 & 1.27 & 1.17 \\
\hline ST & 23899 & 24209 & 58212 & 55541 & 34313 & 31332 & 1.44 & 1.29 \\
\hline ZT & 21529 & 21849 & 54791 & 51883 & 33262 & 30035 & 1.54 & 1.37 \\
\hline SEm \pm & - & - & 870 & 952 & 870 & 952 & 0.04 & 0.04 \\
\hline $\mathrm{CD}(\mathrm{P}=\mathbf{0 . 0 5})$ & - & - & 2609 & 2855 & NS & NS & 0.11 & 0.11 \\
\hline
\end{tabular}


Table.4 Economics of rice-wheat cropping system as influenced by irrigation, NPK levels and crop establishment methods

\begin{tabular}{|c|c|c|c|c|c|c|c|c|}
\hline \multirow[b]{2}{*}{ Treatment } & \multicolumn{2}{|c|}{ Cost of cultivation } & \multicolumn{2}{|c|}{ Gross return } & \multicolumn{2}{|c|}{ Net return } & \multicolumn{2}{|c|}{ B:C ratio } \\
\hline & 2013-14 & $2014-15$ & 2013-14 & $2014-15$ & $2013-14$ & $2014-15$ & $2013-14$ & 2014-15 \\
\hline \multicolumn{9}{|l|}{ Irrigation level } \\
\hline $\begin{array}{c}6 \text { DADSW/ } \\
\text { IW:CPE } 0.5\end{array}$ & 57847 & 63837 & 122113 & 122023 & 64266 & 58186 & 1.12 & 0.91 \\
\hline $\begin{array}{c}3 \text { DADSW/ } \\
\text { IW:CPE } 0.75\end{array}$ & 59407 & 65037 & 124925 & 125808 & 65518 & 60772 & 1.11 & 0.93 \\
\hline SEm \pm & - & - & 1343 & 1589 & 1343 & 1589 & 0.02 & 0.03 \\
\hline $\mathrm{CD}(\mathrm{P}=0.05)$ & - & - & NS & NS & NS & NS & NS & NS \\
\hline \multicolumn{9}{|l|}{ NPK level } \\
\hline $\begin{array}{c}\text { 90:45:30/ } \\
113: 45: 30\end{array}$ & 57219 & 63029 & 116804 & 118701 & 59584 & 55672 & 1.05 & 0.88 \\
\hline $\begin{array}{l}\text { 120:60:40/ } \\
150: 60: 40\end{array}$ & 60034 & 65844 & 130235 & 129130 & 70200 & 63285 & 1.18 & 0.96 \\
\hline SEm \pm & - & - & 1343 & 1589 & 1343 & 1589 & 0.02 & 0.03 \\
\hline $\mathrm{CD}(\overline{\mathrm{P}}=0.05)$ & - & - & 4634 & 5483 & 4634 & 5483 & 0.08 & NS \\
\hline \multicolumn{9}{|c|}{ Crop establishment method } \\
\hline $\mathrm{PT} / \mathrm{CT}$ & 63964 & 69764 & 127456 & 131597 & 63493 & 61833 & 0.99 & 0.89 \\
\hline UPT/RT & 57114 & 62914 & 123598 & 125803 & 66485 & 62890 & 1.16 & 1.00 \\
\hline ZTT /ZT & 54804 & 60634 & 119503 & 114346 & 64699 & 53713 & 1.18 & 0.88 \\
\hline SEm \pm & - & - & 1743 & 1239 & 1743 & 1239 & 0.03 & 0.02 \\
\hline $\mathrm{CD}(\mathrm{P}=0.05)$ & - & - & 5227 & 3716 & NS & 3716 & 0.09 & 0.06 \\
\hline
\end{tabular}

\section{Effect on economics}

\section{Rice}

Irrigation level had no significant effect on gross return, net return and benefit-cost ratio of rice during both the years (Table 2). The higher dose of NPK recorded significantly 13.6 and 6.4 percent higher gross return than lower dose in 2013 and 2014, respectively (Table 2). The higher net return and $\mathrm{B}$ : $\mathrm{C}$ ratio were also achieved in higher NPK dose during both the years. The increase in net return and B: C ratio was 25.5 and 12.2 percent in 2013 and 10.7 and 5.8 per cent in 2014. PT recorded the highest gross return (Rs. 68006 and Rs.74030 ha ${ }^{-1}$ ) followed by UPT (Rs. 65387 and Rs.70263ha ${ }^{-1}$ ) and ZTT (Rs. 64712 and Rs. 62464ha ${ }^{-1}$ ) in 2013 and 2014, respectively. UPT gave the highest net return (Rs.32172 ha ${ }^{-1}$ and Rs. 31558 ha $^{-1}$ ) during both the years. ST also gave the highest $\mathrm{B}$ : C ratio (0.97 and 0.82) during both the years. Mishra and Singh (2007) also reported that the minimum net return and $\mathrm{B}$ : $\mathrm{C}$ ratio was in transplanted rice due to higher cost of production. Singh et al., (2004) also reported that higher net return under reduced puddling than conventional intensive puddling.

\section{Wheat}

There was no significant effect of irrigation levels on gross return, net return and benefit: cost ratio in wheat as both the irrigation levels received only one irrigation in CRI stage due to good amount of seasonal rainfall (Table 3). The higher dose of NPK recorded significantly 9.1 and 11.9 percent higher gross return than lower dose in 2013-14 and 201415, respectively. Higher dose of NPK also 
gave higher net return and $\mathrm{B}$ : $\mathrm{C}$ ratio than lower dose in both the years. The increase in net return and $\mathrm{B}$ : $\mathrm{C}$ ratio was 11.1 and 4.3 percent in 2013-14 and 17.5 and 9.8 per cent 2014-15, respectively (Table 3). CT recorded the highest gross return (Rs. 59450 and Rs.57657 ha ${ }^{-1}$ ) followed by ST (Rs. 58212 and

Rs.55541

$\mathrm{ha}^{-1}$ ) and ZT (Rs.54791 and Rs. $51883 \mathrm{ha}^{-1}$ ) in 2013-14 and 2014-15, respectively. ST gave the highest net return (Rs. 34313 and Rs. $33332 \mathrm{ha}^{-1}$ ) followed by CT (Rs. 33302 and Rs. $31108 \mathrm{ha}^{-1}$ ) and ZT (Rs. 33262 and Rs. $30035 \mathrm{ha}^{-1}$ ) in 2013-14 and 2014-15, respectively. ZT gave the highest $\mathrm{B}$ : $\mathrm{C}$ ratio (1.54 and 1.37) followed by ST (1.44 and 1.29) and CT (1.27 and 1.17) in 2013-14 and 2014-15, respectively. The highest B: $\mathrm{C}$ ratio was achieved in ZT due to lower cost of cultivation than ST and CT. The highest B: C ratio under zero till sowing is in conformity with Brar et al., (2011).

\section{Rice-wheat system}

There was no significant effect of irrigation levels on gross return, net return and benefit: cost ratio in rice-wheat system (Table 4). The higher dose of NPK recorded significantly 11.5 and 8.8 percent higher gross return than lower dose in 2013-14 and 2014-15, respectively. Higher dose of NPK to both the rice-wheat crops gave $17.8 \& 12.4$ per cent and $13.7 \& 9.1$ per cent higher net return and B: C ratio than lower dose of NPK in 2013-14 and 2014-15, respectively (Table 4). PT-CT system recorded the highest gross return (Rs. 127456 and Rs.131597 ha ${ }^{-1}$ ) followed by UPT-ST system (Rs. 123598 and Rs.125803 $\mathrm{ha}^{-1}$ ) and ZTT- ZT system (Rs.119503 and Rs.114346 $\mathrm{ha}^{-1}$ ) in 2013 and 2014, respectively. When both rice and wheat crops were grown under reduced tillage, gave the highest system net return (Rs. 66485 and Rs. $62890 \mathrm{ha}^{-1}$ ) in 2013-14 and 2014-15, respectively. In 2013-14, rice-wheat system with zero tillage gave the highest $\mathrm{B}$ : $\mathrm{C}$ ratio (1.18), while in 2014-15 it was with reduced tillage (1.0). Singh et al., (2004) also reported that among the different tillage systems reduced tillage system gave the highest net returns and $\mathrm{B}$ : $\mathrm{C}$ ratio.

It can be concluded that in silty clay loam soil reduced tillage (unpuddled transplanting in rice and shallow tillage in wheat) are the best bet options against conventional system. Both the crops need to be fertilized at recommended level. For irrigation application, 6 DADSW for rice and IW: CPE 0.50 for wheat after CRI may be followed.

\section{Acknowledgements}

The authors are thankful to the Head, Department of Agronomy and Director of N. E. Borlaug Crop Research Centre of G.B. Pant University of Agriculture and Technology for providing the required research facilities.

\section{References}

Ardell, D., Halvorson, A. L., Black, J. N., Krupingley, S. D., Merril, B. J., Wienhold, G. and Tonaka, K. I. 2001. Spring wheat response to tillage system and nitrogen fertilization within crop fallow system. Agronomy Journal. 92: 151.

Bisht, P. S., Pandey, P. C. and Singh, D. K. 2006. Monitoring of long-term fertility experiment after two decades of rice-wheat cropping. 2nd Int. Rice Congress. Science tech. and trade for peace and prosperity Oct. 9-12, 2006, New Delhi, pp 400.

Brar, A. S., Mahal, S. S., Buttar, G. S. and Deol, J. S. 2011. Water productivity, economics and energetic of basmati rice (Oryza sativa) wheat (Triticum aestivum) under different method of crop establishment. Indian Journal of Agronomy 56 (4): 317-320

Chauhan, D. G. and Ward, K. J. 1992. Cereal emergence and establishment in conservation tillage system. Columbia basin Agric.Res., 
Oregon Agric. Exp. Stn. Spec. Rep. 894. Oregon State Uni, Pendleton.

Dash, R. and Verma, S. C. 2003. Management of weeds, nitrogen and tillage operations in wheat (Triticum aestivum) sown after puddled rice (Oryza sativa). Indian Journal of Agricultural Sciences 73 (5): 286-288.

Fan, M., Jiang, R., Liu, X., Zhang, F., Lu, S., Zeng, $X$. and Christie, P. 2005. Interactions between non-flooded mulching cultivation and varying nitrogen inputs in rice-wheat rotations. Field Crops Research 91(2-3): 307-318.

Gupta, M., Bali, A. S., Kour, S., Bharat, R. and Bazaya, B. R. 2011. Effect of tillage and nutrient management on resources conservation and productivity of wheat (Triticum aestivum). Indian Journal of Agronomy 56 (2): 116-120.

Hobbs, P. R. and Morris, M. 1996. Meeting South Asia's food requirements from rice-wheat cropping systems: priority issues facing researchers in the post-green revolution era. Natural Resource Group Paper 96-01. Mexico, D.F: CIMMYT.

Kibe, A. M., Singh, S. and Kalra, N. 2006. Waternitrogen relationships for wheat growth and productivity in late sown conditions, Agricultural Water Management, 8 (4): 221228.

Kumar, R. and Yadav, D. S. 2005. Effect of zero and minimum tillage in conjunction with nitrogen management in wheat after rice. Indian Journal of Agronomy 50 (1): 54-57.

Ladha, J. K., Fischer, K. S., Hossain, M., Hobbs, P. R. and Hardy, B. 2000. Improving the productivity and sustainability of rice-wheat systems of the Indo-Gangetic Plains: A synthesis of NARS-IRRl partnership research. IRRl Discussion Paper Series No.40. pp. 31. IRR1, Los Balios, Philippines.

Lawlor, D. W. and Cornic, G. 2002. Photosyntetic carbon assimilation and associated metabolism in relation to water deficits in higher plants. Plant Cell Environment 25: 275-294.

Lourduraj, A. C. and Bayan, H. C. 1999. Irrigation management in lowland rice $-\mathrm{a}$ review. Agricultural Reviews 20:185-192.

Mishra, J. S. and Singh, V.P. 2007. Integrated weed management in zero-till direct-seeded rice (Oryza sativa) - wheat (Triticum aestivum) cropping system. Indian Journal of Agronomy 52 (3): 198-203.

Mundra, M. C., Singh, B. P., Rinwa, R.S. and Gupta, S. C. 2003. Crop productivity, returns and soil sustainability under rice-wheat cropping system. Indian Journal of Agronomy 48: 247-250.

Pradhan, S., Bandyopadhya, K. K., Sahoo, R. N., Sehgal, V. K., Singh, R., Joshi, D. K. and Gupta, V. K. 2013. Prediction of wheat (Triticum aestivum) grain and biomass yield under different irrigation and nitrogen management practices using canopy reflectance spectra model. Indian Journal of Agricultural Sciences 83 (11): 1136-1143.

Singh, G., Singh, O. P., Kumar, V. and Kumar, T. 2008. Effect of methods of establishment and tillage practices on productivity of rice (Oryza sativa) - wheat (Triticum aestivum) cropping system in lowlands. Indian Journal of Agricultural Sciences 78 (2): 163-166.

Singh, S., Tripathi, R. P., Sharma, P. and Kumar, R. 2004. Effect of tillage on root growth, crop performance and economics of rice (Oryza sativa)-wheat (Triticum aestivum) system. Indian Journal of Agricultural Sciences 74: 300-304.

Surin, S. S., Singh, M. K., Upasani, R. R., Thakur, R. and Pal, S. K. 2013. Weed management in rice (Oryza sativa)-wheat (Triticum aestivum) cropping system under conservation tillage. Indian Journal of Agronomy 58 (3): 288-291.

\section{How to cite this article:}

Tanumay Mandal, Subhash Chandra and Gurvinder Singh. 2018. Productivity and Economics of Rice-Wheat Cropping System under Irrigation, Nutrient and Tillage Practices in a Silty Clay Loam Soil. Int.J.Curr.Microbiol.App.Sci. 7(03): 823-831. doi: https://doi.org/10.20546/ijcmas.2018.703.096 